\title{
Seasonal variability of Serum 25-Hydroxy-Vitamin D levels in the adult population living in Bilecik province: A follow-up study from Turkey
}

\section{Bilecik ilinde yaşayan yetişkin popülasyonda Serum 25-Hidroksi-D Vitamini düzeylerinin mevsimsel değişimi: Türkiye'den bir takip çalışması}

\author{
Saadet ÇELIK ${ }^{1} \oplus$, Mehmet ÇELIK ${ }^{2}$, Mümtaz TAKIR ${ }^{3} \oplus$
}

\section{ABSTRACT}

\begin{abstract}
Aim: Vitamin D is one of the major hormones involved in phosphorus metabolism in the secosteroid structure. Studies have shown that low serum vitamin D levels are associated with chronic diseases such as autoimmune diseases, diabetes mellitus, hypertension and cancer. The aim of this study was to investigate the seasonal variability of serum 25- hydroxyvitamin D levels in the adult population (18-98) according to age and gender in Bilecik province, Turkey.
\end{abstract}

Methods: The medical records of the patients admitted to hospital between January 2016 and December 2017 were retrospectively screened. The medications of the patients were evaluated. Serum vitamin D levels of 22205 patients were evaluated according to age, gender and seasons.

Results: According to the data, serum vitamin $D$ were analyzed from the sera of 17070 females (76,9\%) and 5135 males (23.1\%). The median values of serum vitamin D levels of the participants were $17.2 \mathrm{ng} / \mathrm{ml}$ $(4.2-137.9 \mathrm{ng} / \mathrm{ml})$ in females and $22.9 \mathrm{ng} / \mathrm{ml}(4.3-144.0 \mathrm{ng} / \mathrm{ml})$ in males. According to the seasonal classification, deficient serum $25-\mathrm{OH}$ vitamin $D$ levels were detected in all seasons in females and in males $(p<0.001)$. Unlike men, vitamin $D$ deficiency was detected in women during the spring $(p<0.001)$. For all subjects, median serum $25-\mathrm{OH}$ vitamin $D$ levels were $20.2 \mathrm{ng} / \mathrm{mL}(4.33-127.2 \mathrm{ng} / \mathrm{mL}), 16.3 \mathrm{ng} / \mathrm{mL}(4.23-144.0 \mathrm{ng} / \mathrm{mL})$, $18.6 \mathrm{ng} / \mathrm{mL}(4.20-129.0 \mathrm{ng} / \mathrm{mL})$ and $19.6 \mathrm{ng} / \mathrm{mL}(4.30-137.9 \mathrm{ng} / \mathrm{mL})$ for autumn, spring, winter, and summer seasons, respectively.

Conclusion: Vitamin D deficiency is prevalent among adults in Bilecik. The serum 25-Hydroxy-Vitamin D Levels were higher in the males than in the females for all seasons $(p<0.001)$. We recommend vitamin $D$ supplementation for adults with additional sunlight exposure.

Keywords: Vitamin D deficiency, gender, age öz

\begin{abstract}
Amaç: $D$ vitamini, secosteroid yapısındaki fosfor metabolizmasında rol oynayan başlıca hormonlardan biridir. Çalışmalar, düşük serum $D$ vitamini düzeylerinin otoimmün hastalıklar, diyabetes mellitus, hipertansiyon ve kanser gibi kronik hastalıklarla ilişkili olduğunu göstermiştir. Bu çalışmanın amacı, Bilecik ilinde yaş ve cinsiyete göre yetişkin popülasyonda (18-98) serum 25-hidroksivitamin D düzeylerinin mevsimsel değişkenliğini araştırmaktır.
\end{abstract}

Yöntemler: Ocak 2016 ile Aralık 2017 tarihleri arasında hastaneye başvuran hastaların dosyaları retrospektif olarak tarandı. Hasta ilaçları değerlendirildi. Yirmi iki bin iki yüz beş hastanın serum D vitamini düzeyleri yaşa, cinsiyete ve mevsimlere göre değerlendirildi.

\begin{abstract}
Bulgular: On yedi bin yetmiş kadın $(\% 76,9)$ ve 5135 erkek $(\% 23,1)$ hastanın serumdan $D$ vitamini analiz edildi. Katılımcıların serum $D$ vitamini düzeylerinin ortanca değeri kadınlarda 17,2 (4,2-137,9), erkeklerde 22,9 $(4,3-144,0)$ idi. Mevsimsel sınıflandırmaya göre, erkekler ve kadınlarda her mevsimde serum 25-OH D vitamini yetersizliği saptandı $(p<0,001)$. Erkeklerden farklı olarak kadınlarda bahar ayında vitamin $D$ eksikliği saptandı $(p<0,001)$. Tüm hastalar için medyan serum $25-\mathrm{OH} D$ vitamini seviyeleri sonbahar, ilkbahar, kış, yaz için sırasıyla 20,2 (4,33-127,2), 16,3 $(4,23-144,0), 18,6(4,20-129,0)$ ve $19,6(4,30-137,9) \mathrm{ng} / \mathrm{mL}$ idi.
\end{abstract}

Sonuç: Bilecik'te yetişkinler arasında yetersiz D vitamini yaygındır. Serum 25-Hidroksi-D vitamini seviyeleri erkeklerde her mevsimde kadınlara göre daha yüksekti $(p<0,001)$. $25(\mathrm{OH}) D$ seviyesinin kadınlarda ve ilkbaharda anlamlı derecede düşük olması dikkat çekicidir $(p<0,001)$. Yetişkinler için güneşışığına maruz kalmalarına ek olarak D vitamini takviyesi önermekteyiz.

Anahtar kelimeler: D vitamini eksikliği, cinsiyet, yaş

\section{Received: 19.04 .2018}

Accepted: 28.08 .2018

${ }^{1}$ Bilecik Public Health Laboratory, Department of Medical Biochemistry, Bilecik, Turkey

${ }^{2}$ Bilecik State Hospital, Department of Endocrinology and Metabolism, Bilecik, Turkey

${ }^{3}$ Istanbul Medeniyet University Göztepe Training and Research Hospital, Department of Endocrinology and Metabolism, Istanbul, Turkey

Corresponding author: Saadet Çelik, Bilecik Public Health Laboratory, Department of Medical Biochemistry, Bilecik, Turkey

e-mail: saadetkader@hotmail.com

ORCID ID's:

S.Ç. 0000-0003-0646-946X, M.Ç. 0000-0001-7364-370X, M.T. 0000-0003-4363-3193 


\section{INTRODUCTION}

Vitamin D, which is predominantly synthesized from the skin with the effect of sunlight, is directly related to the skin's Zenith Angle ${ }^{1}$. Vitamin D is most conveniently synthesized within the time period between 10:00 and 15:00 pm during May and November in our country's geographic latitude. Serum 25 hydroxy $(\mathrm{OH})$ vitamin $\mathrm{D}$ levels are considered to reflect vitamin D status. Levels above $30 \mathrm{ng} / \mathrm{ml}(75 \mathrm{nmol} / \mathrm{L})$, between 20 and $30 \mathrm{ng} / \mathrm{ml}(50-75 \mathrm{nmol} / \mathrm{L})$ and below $20 \mathrm{ng} / \mathrm{ml}$ ( $50 \mathrm{nmol} / \mathrm{L}$ ) are considered to be sufficient, inadequate and deficient, respectively ${ }^{2}$. In this study, our aim was to identify the seasonal variability of serum 25-hydroxyvitamin $D$ levels in the adult population (18-98) according to age and gender in Bilecik province, Turkey.

\section{MATERIAL and METHODS}

The medical records of the patients admitted to hospital between January 2017 and December 2017 were retrospectively screened. Serum vitamin D levels of 22205 patients were retrospectively screened according to age, gender and seasonal variation. Patients with celiac disease, chronic liver disease, stage 3,4,5 chronic kidney disease were excluded from this study. Chronic kidney disease staging was based on the National Kidney Foundation (NKF) criteria for chronic renal failure staging. Patients with GFRs (glomerular filtration rate) as 30 to $59 \mathrm{ml} / \mathrm{min} / 1.73$ $\mathrm{m}^{2} ; 15$ to $29 \mathrm{ml} / \mathrm{min} / 1.73 \mathrm{~m}^{2}$, and $<15 \mathrm{ml} / \mathrm{min} / 1.73$ $\mathrm{m}^{2}$ were considered to have Stage 3,4 , and 5 renal disease. GFR, for kidney diseases calculated using the adapted Modification of Diet in Renal Disease (MDRD) formula ${ }^{3}$.

Patients with a diagnosis of celiac disease in the follow-up files for celiac disease or anti-endomysium and/or anti-gliadin positive for the celiac disease or patients with the suspected celiac disease based on gastrointestinal biopsy findings were excluded from the study. Patients with chronic liver disease according to the their medical file records were excluded from the study. Levels above $30 \mathrm{ng} / \mathrm{ml}(75 \mathrm{nmol} / \mathrm{L})$, between 20 and $30 \mathrm{ng} / \mathrm{ml}(50-75 \mathrm{nmol} / \mathrm{L})$ and below 20 $\mathrm{ng} / \mathrm{ml}(50 \mathrm{nmol} / \mathrm{L})$ were considered to have sufficient, inadequate and deficient serum vitamin D levels, respectively. Serum levels of vitamin D were determined by the chemiluminescence method in Siemens Advia Centaur XP (Siemens Healthcare Diagnostics, Tarrytown, NY, USA) using the kit of the same company. This study was approved by the local ethics committee of Bilecik Provincial Health Directorate (2018/1538).

\section{Statistical Analysis}

Statistical analyses were performed with SPSS 22.0 (Statistical Package for Social Sciences, Armonk, NY: IBM Corp., 2013). In normally distributed groups, the results were presented with mean $\pm S D$, otherwise with medians. The significance of the differences between groups was determined by Student's unpaired t-test for data with normal distributions, and by the Mann-Whitney $U$ test for data with non-normal distribution. The $p$-values of less than 0.05 was accepted as the significance level.

\section{RESULTS}

Vitamin D levels of 22205 patients in Bilecik province between January 2016 and December 2017 were evaluated. The study population consisted of 17070 (76.9\%) female and 5135 (23,1\%) male participants. The median value of serum vitamin $D$ levels of the participants was $17.2 \mathrm{ng} / \mathrm{ml}(4.2-137.9 \mathrm{ng} / \mathrm{ml})$ in females and $22.9 \mathrm{ng} / \mathrm{ml}(4.3-144.0 \mathrm{ng} / \mathrm{ml})$ in males $(p<0.001)$. Seasonal variability of serum 25 -HydroxyVitamin D Levels in the adult population living in $\mathrm{Bi}$ lecik Province is shown in Table 1.

According to the seasonal classification, there was deficiency in serum $25-\mathrm{OH}$ vitamin D levels in all seasons except autumn in males while the females had inadequate serum $25-\mathrm{OH}$ vitamin D levels in all seasons and are more deficient especially in spring. The lowest values were $19.9 \mathrm{ng} / \mathrm{mL}$ for males in spring and $\mathbf{1 5 . 0}$ for females in the same season. For all subjects, median serum 25-OH vitamin D levels were 20.2 $\mathrm{ng} / \mathrm{mL}(4.33-127.2 \mathrm{ng} / \mathrm{mL}), 16.3 \mathrm{ng} / \mathrm{mL}$ (4.23-144.0 $\mathrm{ng} / \mathrm{mL}), 18.6 \mathrm{ng} / \mathrm{mL}(4.20-129.0 \mathrm{ng} / \mathrm{mL})$ and 19.6 $\mathrm{ng} / \mathrm{mL}(4.30-137.9 \mathrm{ng} / \mathrm{mL})$ for autumn, spring, winter, and summer seasons, respectively (Figure 1). According to these values, $25-\mathrm{OH}$ vitamin D levels were 
Table 1. Seasonal variability of serum 25-Hydroxy-Vitamin D levels in the adult population living in Bilecik province.

\begin{tabular}{|c|c|c|c|c|c|c|}
\hline Seasons & $\begin{array}{l}\text { Number of } \\
\text { subjects (n) }\end{array}$ & $\begin{array}{l}25(\mathrm{OH}) \mathrm{D} \mathrm{ng} / \mathrm{mL} \\
\text { Mean } \pm \mathrm{SD}\end{array}$ & $\begin{array}{l}25(\mathrm{OH}) \mathrm{D}<20 \mathrm{ng} / \mathrm{mL} \\
\mathrm{n}(\%)\end{array}$ & $\begin{array}{l}25(\mathrm{OH}) \mathrm{D}: 20-30 \mathrm{ng} / \mathrm{mL} \\
\mathrm{n}(\%)\end{array}$ & $\begin{array}{l}25(\mathrm{OH}) \mathrm{D}>30 \mathrm{ng} / \mathrm{mL} \\
\mathrm{n}(\%)\end{array}$ & $\mathbf{P}$ \\
\hline \multicolumn{7}{|l|}{ Autumn } \\
\hline Female & 6832 & $18.5(4.33-127.2)$ & 54.3 & 28.9 & 16.8 & \multirow[t]{2}{*}{$p<0.001$} \\
\hline Male & 2009 & $24.8(5.30-127.2)$ & 30.8 & 40.9 & 28.4 & \\
\hline \multicolumn{7}{|l|}{ Winter } \\
\hline Female & 3899 & $17.5(4.20-129.1)$ & 59.8 & 23.7 & 16.5 & \multirow[t]{2}{*}{$p<0.001$} \\
\hline Male & 1201 & $21.5(4.33-118.0)$ & 41.3 & 40.4 & 18.3 & \\
\hline \multicolumn{7}{|l|}{ Spring } \\
\hline Female & 4706 & $15.1(4.23-127.1)$ & 64.8 & 20.8 & 14.4 & \multirow[t]{2}{*}{$p<0.001$} \\
\hline Male & 1359 & 19.9 (4.81-144.0) & 50.2 & 35.4 & 14.4 & \\
\hline \multicolumn{7}{|l|}{ Summer } \\
\hline Female & 3560 & 17.6 (4.30-137.9) & 57.6 & 26.8 & 15.6 & \multirow[t]{2}{*}{$p<0.001$} \\
\hline Male & 1128 & 25.1 (4.64-104.6) & 30.2 & 43.2 & 26.6 & \\
\hline
\end{tabular}

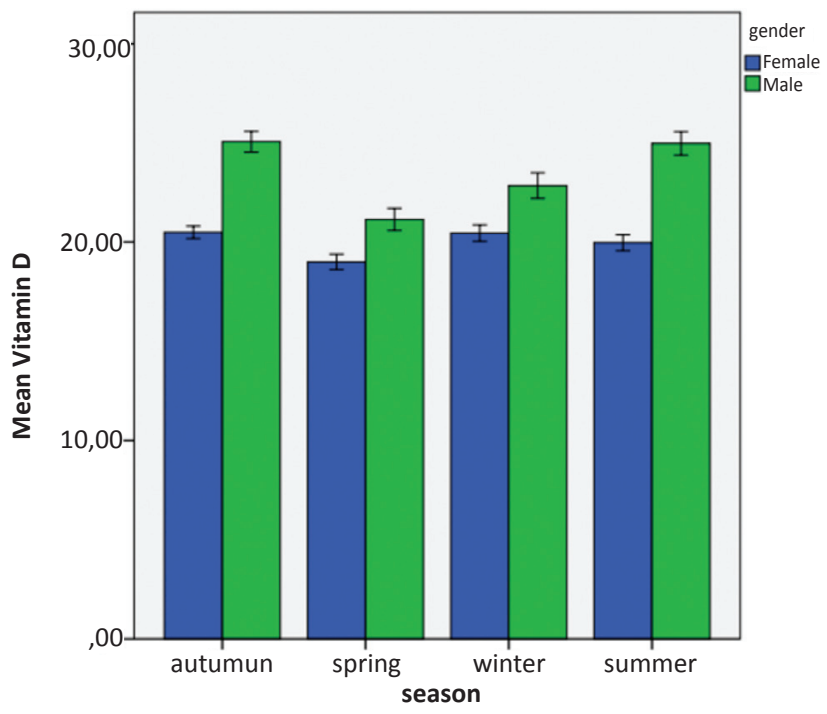

Figure 1. Seasonal variations in serum vitamin $D$ according to gender.

significantly higher in summer vs spring, winter vs spring, autumn vs spring and winter (for all $p<0.001$ ). Also, levels were found to be significantly higher in summer compared to winter $(p=0.012)$. and higher in autumn compared to summer $(p=0.003)$. There was a significant positive correlation between age and serum 25-OH vitamin D levels ( $r=0.058, p<0.001)$.

\section{DISCUSSION}

Serum $25(\mathrm{OH})$ vitamin D level is considered to be the gold standard to present body's vitamin D status. Although there is no consensus on the optimal level of serum vitamin $D$, most authors reported the serum vitamin $D$ levels between 20 and $30 \mathrm{ng} / \mathrm{mL}$ as inadequate and the levels below $20 \mathrm{ng} / \mathrm{mL}$ as a deficien$\mathrm{cy}^{2}$. There are no consensus on the optimal serum 25 $(\mathrm{OH})$ vitamin D levels for bone health. The American Institute of Medicine (IOM) and American Geriatric Society recommend that serum $25(\mathrm{OH}) \mathrm{D}$ levels should be above $20 \mathrm{ng} / \mathrm{ml}$ and $30 \mathrm{ng} / \mathrm{ml}$, respectively to minimize the risk of falls and fractures ${ }^{4-8}$. Although there is no wide-ranging study to determine vitamin $D$ levels in our country, due to the reduced risk of falls. Osteoporosis and Metabolic Bone Diseases Working Group in the Turkey Endocrinology and Metabolism Society defined optimal, insufficient, deficient, and severely deficient serum $25(\mathrm{OH})$ vitamin D levels as $>30 \mathrm{ng} / \mathrm{ml} ; 20-30 \mathrm{ng} / \mathrm{ml} ;<20 \mathrm{ng} / \mathrm{mL}$ and $<10 \mathrm{ng} / \mathrm{ml}$, respectively. It is estimated that approximately one billion people in the world suffer from vitamin $D$ deficiency. In the literature, the vitamin D status differs in several countries, even in various regions of the same country. In America and Europe, vitamin D deficiency was reported to be present in $40 \%$ to $100 \%$ of elderly men and women living in a community (not at eventide home) ${ }^{9}$. In the literature, there have been a few studies concerning the incidence of vitamin $D$ deficiency in Turkey ${ }^{10-13}$. In a study by Ogus et al. ${ }^{14}$ mean serum vitamin $D$ level of their patients was $22.80 \pm 13.27 \mathrm{ng} / \mathrm{mL}$. According to the results of this study, $47 \%$ of the serum vitamin $D$ values were under the cut-off value $1<20$ $\mathrm{ng} / \mathrm{mL}$ ) determined for vitamin D deficiency, $28 \%$ of 
them were between (20-30 $\mathrm{ng} / \mathrm{mL}$ ie.insufficiency) and $25 \%$ of the results were considered as as opti$\mathrm{mal}(>30 \mathrm{ng} / \mathrm{mL}$ ) levels . In our study, $33.47 \%$ of the patients were found to have vitamin $D$ deficiency. Different cut-off values in the studies, discrepancies between the measurement methods (tandem-mass spectrometry, radioimmunoassay, and automated immunoassay systems) should be taken into consideration and further standardization studies should be performed for the measurement of vitamin $D$ levels ${ }^{15}$. Measurement of serum 25-hydroxyvitamin $D$ is recommended only in patients with risk for vitamin D deficiency (elder patients, those with dark skin color, obesity, those using drugs affecting vitamin D metabolism, individuals with inadequate exposure to sunlight, osteoporosis, nontraumatic spontaneous fractures, osteomalacia malabsorption syndromes, chronic kidney failure, chronic liver disease, hyperparathyroidism). Although vitamin D deficiency is widespread, population screening is not recommended.

\section{CONCLUSION}

This study determined the seasonal variability of serum vitamin D levels according to age, and gender in a local population. Most of the patients were found to be as vitamin $D$ deficient. There were significantly lower serum vitamin $D$ levels in females compared to males. Evaluation of serum vitamin D levels with other risk factors and bone metabolism is of great importance.

\section{Study limitations}

Limitations of the present study were the lack of information regarding the dietary intake of vitamin $D$ of the participants. The absolute majority of the participants were from Bilecik province, but more detailed information about skin type or color was not obtained. In addition, we do not have the opportunity to include patients who have applied to our primary health care services and follow these patients thereafter. As a result, the study may not be representative of the general population who are from $\mathrm{Bi}$ lecik province.

\section{REFERENCES}

1. Wacker M, Holick MF. Vitamin D-effects on skeletal and extraskeletal health and the need for supplementation. Nutrients. 2013;5(1):111-48.

https://doi.org/10.3390/nu5010111

2. Holick MF. Vitamin D deficiency. N Engl J Med. 2007;357:266-81. https://doi.org/10.1056/NEJM198008143030701

3. Levey AS, Coresh J, Greene T, et al. Chronic Kidney Disease Epidemiology Collaboration. Using standardized serum creatinine values in the modification of diet in renal disease study equation for estimating glomerular filtration rate. Ann Intern Med 2006;145:247-54. https://doi.org/10.7326/0003-4819-145-4-200608150-00004

4. Ross AC, Manson JE, Abrams SA, Aloia JF, Brannon PM, Clinton SK, et al. The 2011 report on dietary reference intakes for calcium and vitamin D from the Institute of Medicine: what clinicians need to know. J Clin Endocrinol Metab. 2011;96(1):53-8.

https://doi.org/10.1210/jc.2010-2704

5. Holick MF, Binkley NC, Bischoff-Ferrari HA, Gordon CM, Hanley DA, Heaney RP, et al. Evaluation, treatment, and prevention of vitamin D deficiency: An endocrine society clinical practice guideline. J Clin Endocrinol Metab. 2011;96:1911-30. https://doi.org/10.1210/jc.2011-0385

6. Vieth R. What is the optimal vitamin D status for health Prog Biophys Mol Biol. 2006;92(1):26-32.

https://doi.org/10.1016/j.pbiomolbio.2006.02.003

7. Dawson-Hughes B, Mithal A, Bonjour JP, Boonen S, Burckhardt $P$, Fuleihan $G E$, et al. IOF position statement: vitamin $D$ recommendations for older adults. Osteoporos Int. 2010;21(7):1151-4.

https://doi.org/10.1007/s00198-010-1285-3

8. American Geriatrics Society Workgroup on Vitamin D Supplementation for Older Adults. Recommendations abstracted from the American Geriatrics Society Consensus Statement on vitamin D for Prevention of Falls and Their Consequences. J Am Geriatr Soc. 2014;62(1):147-52.

https://doi.org/10.1111/jgs.12631

9. Lips P. Vitamin D status and nutrition in Europe and Asia. J Steroid Biochem Mol Biol. 2007;103:620-5. https://doi.org/10.1016/j.jsbmb.2006.12.076

10. Alagöl F, Shihadeh Y, Boztepe H, Tanakol R, Yarman S, Azizlerli $H$, et al. Sunlight exposure and vitamin D deficiency in Turkish women. J Endocrinol Invest. 2000;23(3):173-7. https://doi.org/10.1007/BF03343702

11. Atli T, Gullu S, Uysal AR, Erdoğan G. The prevalence of Vitamin D deficiency and effects of ultraviolet light on vitamin D levels in the elderly Turkish population. Arch Gerontol Geriatr. 2005;40:53-60.

https://doi.org/10.1016/j.archger.2004.05.006

12. Hekimsoy Z, Dinç G, Kafesçiler S, Onur E, Güvenç Y, Pala T, et al. Vitamin $D$ status among adults in the Aegean region of Turkey. BMC Public Health 2010;10:782. https://doi.org/10.1186/1471-2458-10-782

13. Cigerli O, Parildar H, Unal AD, Tarcin O, Erdal R, Guvener Demirag N. Vitamin D deficiency is a problem for adult outpatients A university hospital sample in Istanbul, Turkey. Public Health Nutr. 2013;16(7):1306-13. https://doi.org/10.1017/S1368980012003588

14. Öğüş $E$, Sürer $H$, Kılınç $A$, Fidancı $V$, Yılmaz $G$, Dindar $N$, et al. Evaluation of Vitamin $D$ Levels by months, sex and age. Ankara Medical Journal. 2014;15(1). https://doi.org/10.17098/amj.88875

15. Van den Quweland JM, Beijers AM, Demacker PM, van Daal HM. Measurement of 25-OH-vitamin D in human serum using liquid chromatography tandem-mass spectrometry with the comparison to radioimmunoassay and automated immunoassay. J Chromatogr B Analyt Technol Biomed Life Sci. 2010;878(15-16):1163-8.

https://doi.org/10.1016/j.jchromb.2010.03.035 